\title{
Design and management of the metropolitan green belt of Aburrá Valley, Colombia
}

\author{
L. C. A. Patiño ${ }^{1} \&$ J. L. Miralles i Garcia ${ }^{2}$ \\ ${ }^{1}$ Urban and Regional Planning School, Faculty of Architecture, \\ National University of Colombia, Colombia \\ ${ }^{2}$ Department of Urban Planning, \\ Polytechnic University of Valencia, Spain
}

\begin{abstract}
Medellín is the center of a metropolitan area that occupies part of the Aburrá Valley. Between 2012 and 2013, the National University of Colombia, local office of Medellín, conducted the study Proposal for the Development of the Metropolitan Green Belt of Aburrá Valley. The study aims to develop a project of ecological planning in the metropolitan region around Medellín in Colombia. The area includes 10 municipalities comprising the metropolitan conurbation of Medellín. The project designs an intervention strategy to promote meaningful protection for the provision of ecosystem services urban areas. The project designs an intervention strategy to promote protection of meaningful areas for the urban provision of ecosystem services. The set of strategies has been termed Metropolitan Green Belt of Aburrá Valley. It is defined as three geographical areas of intervention: The External Belt for water regulation, System of Urban-Rural Transition for dissipation and containing urban expansion and Ecological Connection Structure. Each area has been associated with a key concept and a major ecosystem service. The three areas, spatially integrated, constitute the green belt. Seven management strategies have also been raised for a planning horizon of 17 years (consistent with the 2030 vision of the metropolitan city). The work shows the conceptual coherence between ecological conservation goals and objectives of spatial planning. It also reveals the social and political acceptance with planning actions that invoke ideas of ecological conservation. This project was developed between 2012 and 2013 by a team from the National University of Colombia (School of Urban-Regional Planning) and funded by the Metropolitan
\end{abstract}


Area of the Aburrá Valley, a regional government. The authors participated in the project as technical coordination (L. C. A. Patiño) and international consultant (J. L. Miralles i Garcia).

Keywords: regional planning, green infrastructure, ecosystem services, periurban areas.

\section{Introduction}

Medellín is the main town of the metropolitan area of Aburrá Valley in Andean Mountains. This area includes 7 municipalities: Barbosa, Bello, Copacabana, Envigado, Girardota, Itagüí, La Estrella, Medellín and Sabaneta. The valley occupies an area of $1,152 \mathrm{~km}^{2}$ and had a population of about 3.5 million in 2011 .

The urban area occupies most of the valley bottom with an average elevation of 1,500 meters above sea level. The mountains and high plateau around valley has an average elevation about 2,500 meters. The highest peaks reach more of 28,000 meters.

Most of the valley apt to urbanization is already urbanized. In some areas, urbanization reaches the limits of the high plateau. The mountains and high plateau around Aburrá Valley contain valuable ecosystems that supply environmental services to the population of the metropolitan area. Hence the need to establish criteria to conserve and maintain these valuable ecosystems.

Today, rural zones of the metropolitan area have functions such as solid waste landfill, providing food, ecological conservation or recreational amenities. These functions are in conflict with the metropolitan urban expansion process. Urban expansion process, or urbanization process, demands rural spaces to transform into houses, commercial areas, road or highways, facilities, water supply infrastructures, etc. All of these are urban uses to urban functions.

Today, it exit a large international experience in order to maintain valuable ecosystems in the metropolitan areas by green zones around urban areas as a Green Ring of Vitoria Gasteiz [1, 2], Green Belt of Beijing [3, 4], Green Belt of London $[5,6]$ or Green Belt of Caracas [7]. This strategy is to generate and preserve areas without urbanizing in metropolitan surroundings. The objective is to harmonize, by adequate metropolitan plan, rural uses and urban uses in interphase zones to maintain their ecosystem functions.

Aburrá Valley has a metropolitan administration named Metropolitan Area of Aburrá Valley which manages regional planning in this area. The institution has a budget from an environmental tax (99/1993 Act) and a metropolitan tax (128/1994 Act). These incomes allows the promotion of environmental plans and projects to metropolitan area [8-13].

This paper presents the project Green Metropolitan Belt of Aburrá Valley (Cinturón Verde Metropolitano del Valle de Aburrá, CVMVA). It is a case of ecological and regional plan. The project has been realized by a multidisciplinary team of National University of Colombia, local office of Medellín (UNAL team). The team has been directed by Luis Carlos Agudelo and has been formed by Francisco Vásquez, María Fernanda Cárdenas, Jenny Sepúlveda, Adrián Perpiñán, Diana Tobón, Emilse Castrillón, Alejandra Ciro, Pilar Palacio, Lucila Andrea 
Morales, Elizabeth Duque, Pamela Múnera, Alejandro González, Diana C. Zapata, Gloria I. Martínez and Lady Acevedo. It also involved a group of international consultants, which includes José Luis Miralles.

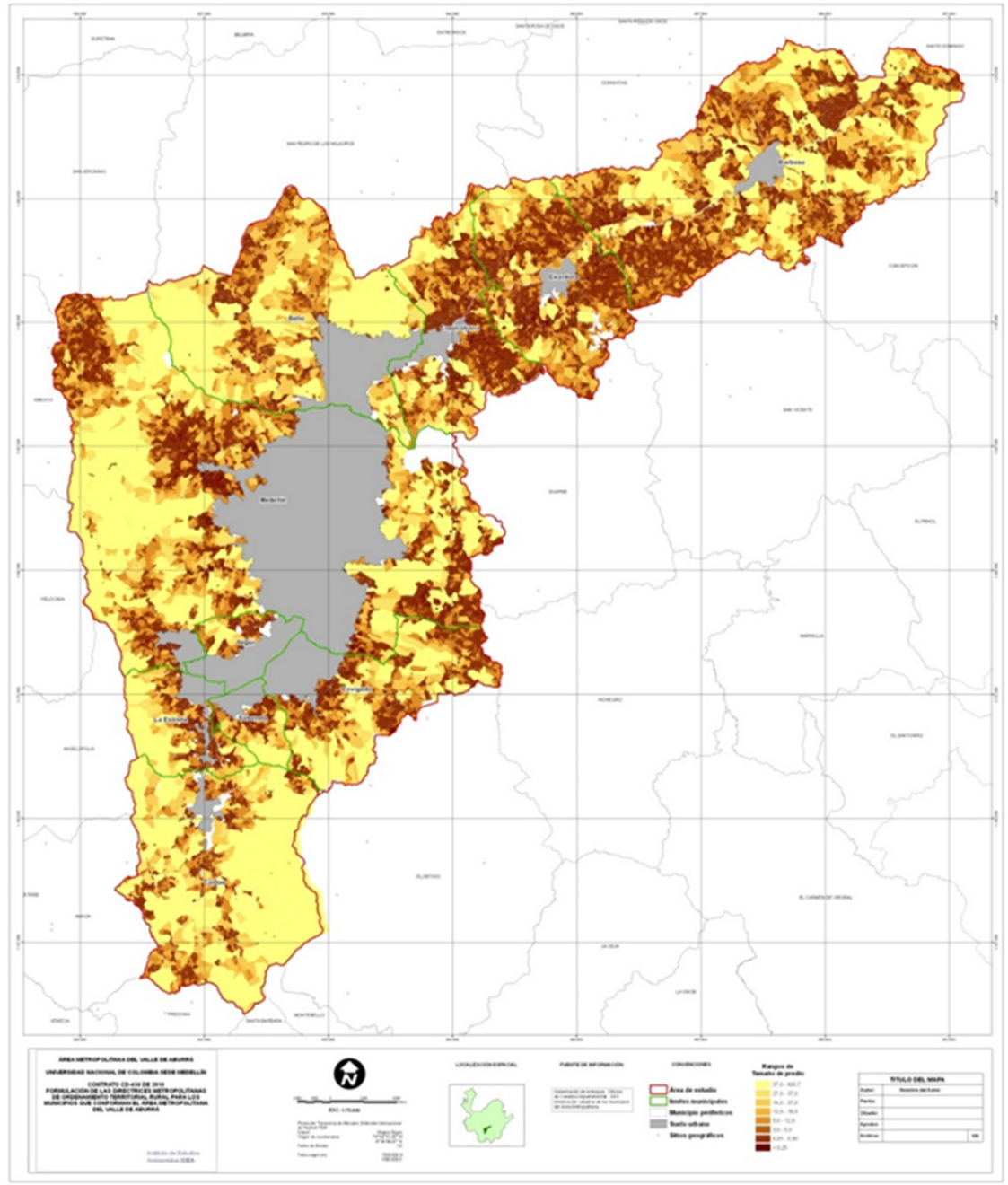

Figure 1: Urban core and urban sprawl to mountainside in metropolitan area of Aburrá Valley.

\section{Previous diagnosis}

Previous studies as performed by López and Vélez [14], Montoya et al. [15], Scheaffer et al. [16], the Govern of Antioquia [17], Estrada Gil [18] and Schnitter et al. [19] allows a first approach to the topic. The research team identified at first 
moment a list of territorial phenomena that justifies a regional planning with metropolitan scale. Specially, we can talk about six main processes:

- Urban core spaces are running out: the zones apt to build or urbanize in the central area have been depleted over time. Today it is necessary to identify new zones where it is good, or not good, to urbanize.

- $\quad$ Endangered Regional Biodiversity: precisely because of urban growth, it exit endangered zones with high environmental value that must be preserved and protected.

- The need to protect borders and rural areas: rural areas in metropolitan borders have crucial roles as providers of natural resources to urban population; this function must be maintained.

- Occupation of mountainsides with natural risks by marginal urban zones: usually by informal urbanization that occupy steep slopes or ravines, often in areas at risk of landslides or floods; in fact, has already produced dramatic catastrophes in the rainy season.

- Urbanization of locations and landscapes of traditional recreation: population has historically been used a number of location as recreation area; it is necessary identify them and design to maintain their functions.

- Inefficiency of legal protection thought as a unique conservation instrument: only the passive legal protection is clearly insufficient to maintain rural and natural uses and functions; it is necessary a more complete and complex vision.

\section{Methodology}

The Green Metropolitan Belt of Aburrá Valley (CVMVA) has been defined as a planning strategy to public interest at long term. It is aimed to protecting zones that provide environmental services and to generate public spaces in metropolitan area. The final goal is increase quality of life of metropolitan population and help to consolidate a more balanced and equitable territory.

CVMVA is not a specific project but a planning strategy for at least the next 12 years. That is, probably the actions can be completely consolidate in 2030 .

Because of the great diversity of spaces that exist in the metropolitan area, the strategy outline three planning fields (Figure 2): External Belt, Transition System Urban-Regional and Structure of Organic Connection.

\subsection{External Belt}

The External Belt is defined as a structure of ecological protection for natural water regulation in the Aburrá Valley. It is bounded by catchment areas of Zero Order. It consists of a set of biotic and abiotic elements that ensure the protection of headwaters and contribute to the regulation of micro basins. There are the foundation to a territorial dynamics with balanced environmental. The character of green belt as a geographical continuous makes it a biological corridor.

The External Belt produces, as the main ecosystem service, hydrological regulation of waters that flow into the Aburrá Valley. Their proper functioning, 


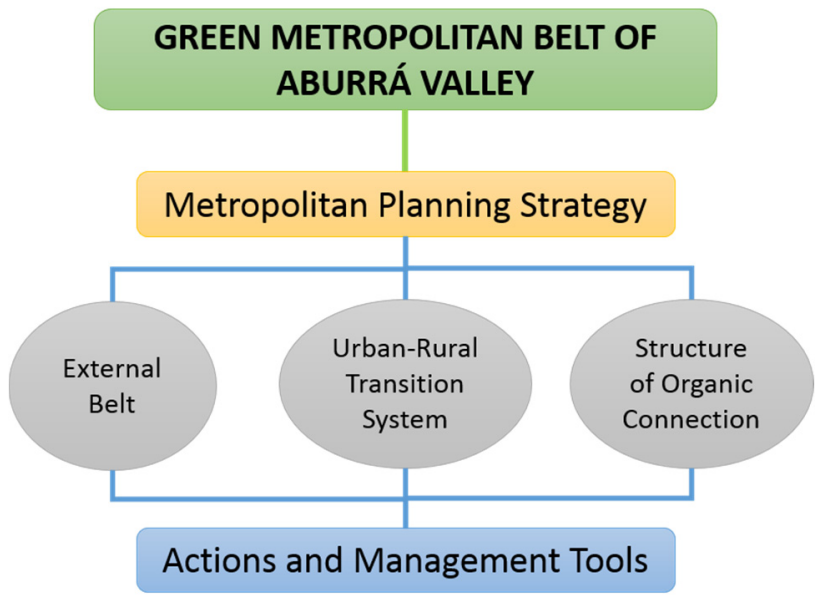

Figure 2: Planning fields in strategy of Green Metropolitan Belt of Aburrá Valley.

that is, maintain, in the full extent, adequate forest cover to facilitate infiltration of water also contributes to the conservation of species, because of effect as a biological corridor, and mitigate the effects of climate change.

Besides the External Belt produces at least two other ecosystem services: water supply to towns and flood control in usual rainfall events.

The fundamental concept used for this field of planning is Catchment Area of Zero Order. It is a scientific interpretation of the traditional notion of "headwater", widely used by Andean farmers to refer to the most sensitive area of a river basin. Figure 3 shows the full methodological process to delimit the CHOC.
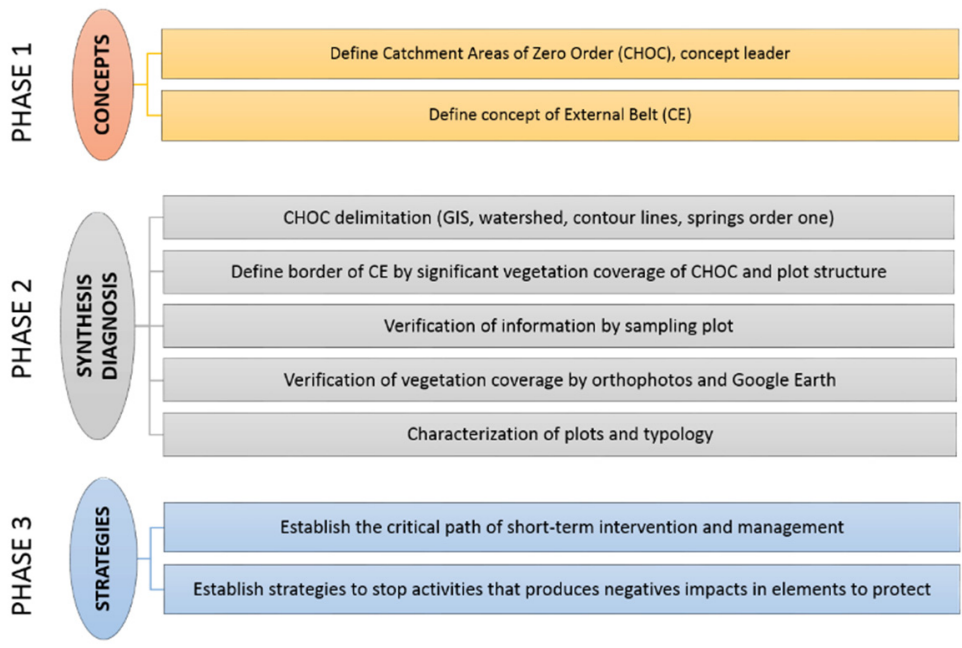

Figure 3: Methodology to External Belt proposal. 


\subsection{Urban-Rural Transition System (STUR)}

The areas where tension between the urban expansion and undeveloped land is most clearly manifested, are called Urban-Rural Transition System (STUR). It is defined as a transition strip with variable amplitude, which includes uses of urban character and traditional rural uses.

The STUR is located in the urban-rural border. This fact exposes it to rapid urbanization. Therefore, the objective in this level of intervention is to harmonize the urban-rural transition. For that:

- $\quad$ Sites that provide ecosystem services are preserved, usually associated with traditional recreation of the inhabitants of the Aburrá Valley;

- Public spaces are anticipated in areas prone to formal and informal urban expansion;

- $\quad$ Spaces already urbanized are balanced with public free areas integrated in metropolitan system. These new metropolitan spaces will be as a minimal equipment with minimal intervention.

The areas suitable for urban development represent the potential of urban expansion in the valley. The suitability depends of topography and exposure to natural hazards.

In this sense, the STUR includes all areas that are occupied by urban or suburban processes and those that have potential for these processes. Thus, by way of example, Medellín has already exceeded the natural capacity of the land, because it has urbanized areas with risks. Meanwhile, a municipality like Barbosa has large areas with potential for urban development still unoccupied. The STUR define a taxonomy of urban-rural borders in the valley and program specific planning responses for each type. One is just the Border Park Urban-Rural. In Figure 4 you can see the methodological process for define the STUR.
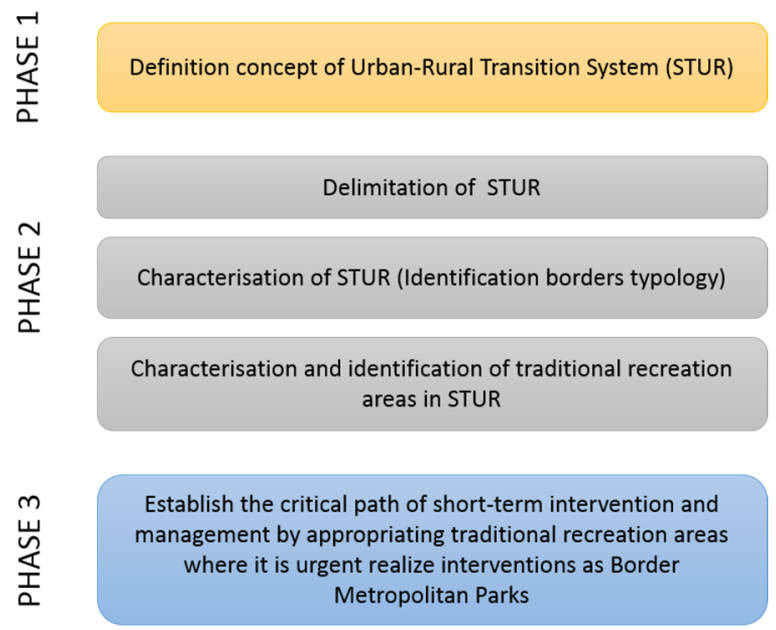

Figure 4: Methodology to Urban-Rural Transition System proposal. 


\subsection{Structure of Ecologic Connection}

The topography of the valley requires physically connection between the two areas already described (External Belt and Transition System) by biological corridors. It is therefore necessary to establish what priority we must have for corridors and on what basis.

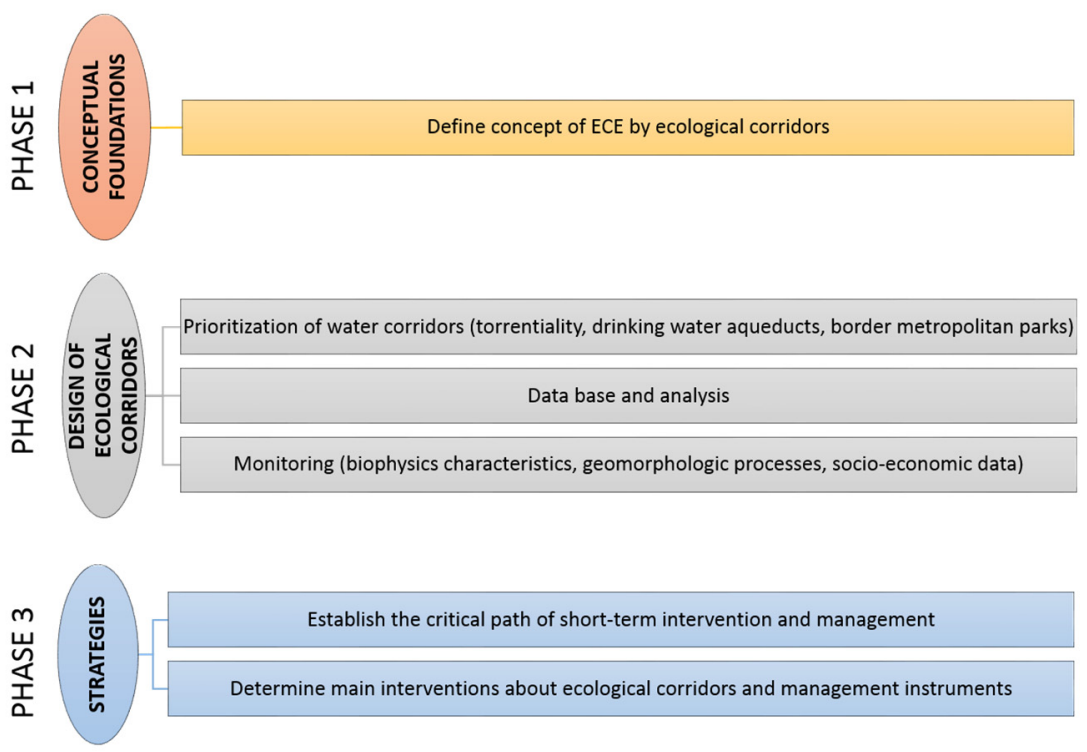

Figure 5: Methodology to Ecological Connection Structure proposal.

Ecological Connection Structure is defined as the spatial arrangement in the regional territory, which strengthens the Green Metropolitan Belt of Aburrá Valley by territorial interventions that link between them the External Belt and the UrbanRural Transition System. Mainly through strips of riparian vegetation, which contribute to water regulation processes and generate additional environmental benefits for the metropolitan territory.

\section{Results}

\subsection{External Belt}

As a result of analysis of Exterior Belt, were obtained and mapped a set of properties that makes up the green belt. In total 6,040 plots with a surface of 28,436 ha. Of them, 5,973 ha out of municipalities of metropolitan area. In this zone, it propose maintain rural and natural uses.

Now, for management this space it is necessary a better understanding of the situation of each property. For this purpose, we have considered two types of properties: 
- Type 1 (T1): These are properties with declaration of regional or municipal protection in force. There is a total $22,560 \mathrm{ha}$, which represent a surface of $19.58 \%$ of the metropolitan jurisdiction. This extension affects 962 properties of External Belt with a surface of 10,730 ha.

- $\quad$ Type 2 (T2): Are the lands of External Belt subject to management tools. There is an area of 10,370 ha (10.18\% of the metropolitan jurisdiction) and includes 5,078 plots. This area will be object of direct management with owners.

In addition, it has also been analysed the specific use of each plot and uses distribution according their size.

\subsection{Urban-Rural Transition System}

According of analysis of Urban-Rural Transition System, the following results were obtained:

- Delimitation of consolidated urban land: In order to establish the limit of STUR, the team identified the "real" urban perimeter of Aburrá Valley. The main criterion for delimitation was the level of consolidation of the existing urban fabric.

- Identification of suitable land to urbanization: By geomorphological criteria and according to the slopes, the team identified suitable lands to urbanization processes.

- Monitoring of territorial configurations in process of rural-urban transition: The work team identified the areas that present specific territorial forms because of processes of urban-rural transition.

- Delimitation of Urban-Rural Transition System: the team overlaid the land suitable to urbanization with already occupied areas showing processes of urban-rural transition. As a result, it is obtained a delimitation of STUR and a mapped taxonomy of borders types.

Finally, it is obtained the identification of areas with the role of Border Metropolitan Parks, totally seventeen parks.

\subsection{Structure of Ecologic Connection}

The criterion of delimitation of the micro basins that make up this structure are the following:

- "Ravines that offer environmental services" specifically water supply for human consumption.

- "Torrential Ravines" where it exit flood risks as a rain flood or flash flood.

- "Connecting Ravines" that connect both External Belt and Urban-Rural System Transition.

The set of all ravines with these functions make up the Structure of Ecological Connection. 


\subsection{Management estrategies}

The general conception of the CVMVA project, by the Metropolitan Area of the Valley of Aburrá entity, involves careful design of instruments of territorial management. These instruments are based on the general principle of fair distribution of burdens and benefits, with a focus on transfer of the benefits of urban development to rural areas with municipal or metropolitan importance.

These have been defined as seven strategies that are outlined below:

1. Regional Planning. Each municipality of Metropolitan Area must include in its urban plan (POT), classified as a land protection, the areas listed in the CVMVA at plot level.

2. Consolidation of Territorial Management Instruments. Each municipality of Metropolitan Area must include in its POT the possibility of transferring urban obligations (provision of plots for facilities or amenities) from urban projects to the areas listed in CVMVA. This transfer can partly finance the management strategies.

3. Consolidation of the System of Metropolitan Border Parks. It is proposed to implement a set of Metropolitan Border Parks to horizon of 12 years. They are aimed at strengthen the supply of public space and rescue traditional recreation places. The design of each park must consider the type of border or Transition Urban-Rural where it would be located. There are 17 parks and affecting 56 plots with a total surface of 898 has.

4. Intervention in critical areas. Prioritizes intervention in the areas that must be ecological protection and currently support uses such as livestock or agriculture without negative environmental impacts or areas that are occupied by houses and buildings in ravines that make up the Ecological System Connection. It is usually plots smaller than $1.7 \mathrm{ha}$, the smallest in the study area.

5. Induced Ecological Restoration. It is promoting the gradual abandonment of areas with livestock or agriculture, for a successful natural regeneration, with a first intervention aimed at Forest Plantations. It is indicated for plots with more to 12 ha. This is the minimal surface allows for a family income equivalent to 3 minimum monthly wage in the forest turn. Until the turn, a trust would manage the money to secure monthly cash flow.

6. Land Stewardship Contracts. That is to pay an annual fee, especially to owners of significant areas of natural forests and shrubs, to maintain and conserve ecological functions. Some of the resources obtained by the Strategy 2 could eventually be used to acquire these areas.

7. Social appropriation - Collective Agreements by the CVM. Collect a set of strategies for communication, owner information and increase awareness to communities and municipal authorities. It relies on videos, brochures, web sites and pages on social networks. 


\section{Conclusions}

Planning strategies aimed at containing urban expansion processes, invoking the ideals of nature and conservation of ecosystems, have social and political acceptance. It is a trend that, in the study area, is consolidated under the name of Green Metropolitan Belt.

The management of protected areas in metropolitan urban areas requires incorporating new strategies to involve the metropolitan farmers and protection of landscapes, ecosystems and places of great social significance.

\section{References}

[1] Anillo Verde de Vitoria-Gasteiz; Ayuntamiento de Vitoria-Gasteiz (2012). http://www.vitoria-gasteiz.org

[2] La Población de Vitoria-Gasteiz al 1/1/2013 y los movimientos demográficos del último año; Ayuntamiento de Vitoria-Gasteiz (2013). http://www.vitoria-gasteiz.org/wb021/http/contenidosEstaticos/adjuntos/ es/85/07/48507.pdf

[3] Barrera, M, Gómez, F., Caro, J. \& Gentil, M. La Ciudad China Contemporánea (Chapter 5). Cruce de miradas, relaciones e intercambios, ed. P. San Ginés Aguilar, Editorial Universidad de Granada: Granada, pp. 81-98, 2010.

[4] Beijing population tops 20.69 million, China Daily; Chinadaily (2013). http://www.chinadaily.com.cn/china/2013-01/20/content_16145961.htm

[5] Department for Communities and Local Government; National Planning Policy Framework, London, 2012. http://www.communities.gov.uk/ documents/planningandbuilding/pdf/2116950.pdf

[6] London Green Belt Council. The History of the London Green Belt. http://www.londongreenbeltcouncil.org.uk/lgbc\%20website/pdf/THE $\% 20$ HISTORY\%20OF\%20THE\%20LONDON\%20GREEN\%20BELT.pdf

[7] Douglas, A. Aplicación del modelo de cinturón verde en la ciudad de Caracas, Venezuela. Provincia, 19, pp. 143-160, 2008. http://www.redalyc.org/articulo.oa? id=55501907

[8] Proyecto Metrópoli 2002-2020. Hacia la integración regional sostenible. Medellín: Dinámica; Área Metropolitana del Valle de Aburrá - AMVA (2002). http://www.metropol.gov.co/compartidos/docs/Metropoli_2008 .pdf

[9] Directrices Metropolitanas de Ordenamiento Territorial: Hacia una región de ciudades. Medellín; Área Metropolitana del Valle de Aburrá - AMVA (2006). $\quad$ http://www.bapp-eafit.info/uploads/docs/Directrices $\% 20$ Metropolitanas\%20de\%20Ordenamiento\%20Territorial.pdf

[10] Plan Integral de Desarrollo Metropolitano. METRÓPOLI 2008-2020. Hacia la integración regional sostenible - PIDM - 2007; Área Metropolitana del Valle de Aburrá - AMVA (2007).

[11] Plan Maestro de Espacios Públicos Verdes Urbanos de la Región Metropolitana del Valle de Aburrá. Medellín: Consorcio Concol - AIM 
(Consultoría Colombiana S.A. - Arredondo Madrid Ingenieros Civiles Ltda.); Área Metropolitana del Valle de Aburrá (2007). http://www.metropol.gov.co/zonasverdes/contenidos.php?seccion=1

[12] Plan de Ordenación y Manejo de la Cuenca del río Aburrá - POMCA Medellín: Universidad Nacional de Colombia; Área Metropolitana del Valle de Aburrá - AMVA, CORNARE, CORANTIOQUIA (2007). http://www.areadigital.gov.co/observatorio/Expedientes\%20Municipales/ Normatividad/POMCA_lineamientos.pdf

[13] Sistema Metropolitano de Áreas Protegidas - SIMAP. Medellín: Universidad de Antioquia - UdeA; Área Metropolitana del Valle de Aburrá - AMVA (2008). http://www.bapp-eafit.info/uploads/docs/Sistema\%20 Metropolitano\%20de $\% 20 \% \mathrm{C} 3 \% 81$ reas $\% 20$ Protegidas\%20SIMAP.pdf

[14] López, Octavio \& Vélez, Gabriel. Estudio de un Cordón Forestal para la ciudad de Medellín (undergraduate thesis). Universidad Nacional del Colombia, Medellín, 1969.

[15] Montoya, L., Silva, S., \& González, J. Evaluación de zonas de amenaza por avenidas torrenciales utilizando metodologías cualitativas. Caso de aplicación a la quebrada Doña María. Revista Ingenierías Universidad de Medellín 8(15), pp. 11-29, 2009. http://webapps.udem.edu.co/ RevistaIngenierias/pdf/v8n15/v8n15a02.pdf

[16] Scheaffer, R., Mendenhall, S. \& Ott, L. Elementos de muestreo. Ed. Grupo Editorial Iberoamérica, México, 1987.

[17] Lineamientos de Ordenación Minero-Ambiental para los Materiales de Construcción en la Cuenca del Río Aburrá - LOMAVA; Secretaria de Minas, Gobernación de Antioquia; Medellín: Consorcio Minero, 2010.

[18] Estrada Gil, L.M. El parque barrial en la planeación y configuración urbana de Medellín. Master's Thesis, Universidad Nacional de Colombia, Sede Medellín, 2012.

[19] Schnitter, P., Giraldo, M.L. \& Patiño J.M. La ocupación del territorio en el proceso de urbanización del Área Metropolitana del Valle de Aburrá, Colombia. Scripta Nova, Revista electrónica de Geografía y Ciencias Sociales, 218 (83), 2006. 